\title{
RENAL REABSORPTION OF PHOSPHATE IN NORMAL HUMAN SUBJECTS AND IN PATIENTS WITH PARATHYROID DISEASE
}

\author{
BY DAVID D. THOMPSON ${ }^{1}$ AND HOWARD H. HIATT 2
}

(From the National Institute of Arthritis and Metabolic Diseases, National Institutes of Health, Public Health Service, U.S. Department of Health, Education and Welfare, Bethesda, Md.)

(Submitted for publication August 30, 1956; accepted December 13, 1956)

A number of studies in the dog and in man $(1-6)$ have demonstrated a maximal renal tubular reabsorptive capacity for phosphate $\left(\mathrm{TmP}^{\mathbf{8}}\right)$. However, some investigators have denied that the reabsorption of phosphate conforms to Tm characteristics (7-9). These workers have suggested that phosphate reabsorption is conditioned by the rate of phosphate filtration such that a fairly constant proportion of the filtered phosphate is reabsorbed. In view of the conflicting evidence and the relative paucity of phosphate titration studies on man, experiments were performed in order to obtain information on the mechanism of phosphate reabsorption, the constancy of reabsorption in any one individual, and its variability in a group of subjects. The data were required for subsequent investigations designed to evaluate the influence of several factors on renal phosphate transport. The studies were performed on normal individuals and in patients with parathyroid disease.

It was found that in any given experiment a TmP was demonstrable. However, the variability in TmP seen in most of our normal subjects between consecutive periods of a single experiment and between experiments generally exceeded the variability reported for glucose $\mathrm{Tm}$ and for $\mathrm{PAH}$ $\mathrm{Tm}$. Furthermore, the range of values for TmP within a group of normal individuals is so large that an average value has little meaning. Fluctuations in TmP in our subjects could not be con-

1 Present address : Department of Physiology, Cornell University Medical College, New York 21, N. Y.

2 Present address: Department of Medicine, Harvard Medical School and Beth Israel Hospital, Boston, Mass.

8 The following abbreviations will be used in this paper: $P$, inorganic phosphate ; $C_{\text {In }}$, inulin clearance; GFR, glomerular filtration rate; $R P F$, effective renal plasma flow; Tm, maximal rate of renal tubular reabsorption; $\mathrm{Ca}$, calcium; $\mathrm{K}$, potassium; $\mathrm{PAH}$, para-amino hippurate. sistently correlated with the level of calcium or phosphate in the diet.

\section{METHODS}

Subjects. Studies were carried out on ten normal subjects, three patients with post-thyroidectomy hypoparathyroidism, and one individual with hyperparathyroidism. The normal individuals included five male and three female volunteers aged 20 to 27 years, one 17-year-old male (C. H.) convalescing from a hip injury, but ambulatory during most of the studies, and a 26-year-old female (W. H.) hospitalized with a diagnosis of hypoparathyroidism, but found to have normal parathyroid function. The hypoparathyroid patients, a 37-year-old male and two females, aged 42 and .52 , had not been treated previously with any medication other than calcium salts. The manifestations of hypoparathyroidism were severe in the male and mild in the females. The hyperparathyroid subject, a 72-year-old male, was subsequently cured by the removal of a parathyroid adenoma.

All subjects were hospitalized on a metabolism ward, and during many of the studies they received constant diets of calculated calcium and phosphate content. There were no restrictions on the patients' activities.

Design of experiments. Studies were begun about 9 a.m. with the patient fasted for 12 to 16 hours. Onehalf hour prior to the start of each study the subject ingested a liter of water and thereafter drank $200 \mathrm{ml}$. of wa-

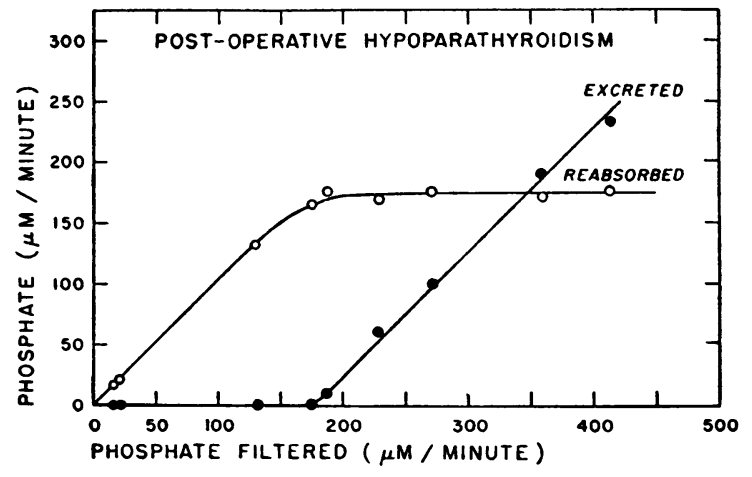

Fig. 1. The Quantities of Phosphate Filtered, Excreted, and Reabsorbed During Intravenous Phosphate Loading in a Hypoparathyroid SUbJect 
TABLE I

Effect of elevation of plasma inorganic phosphate on the quantity of phosphate filtered, excreted, and reabsorbed *

\begin{tabular}{|c|c|c|c|c|c|c|c|c|c|}
\hline \multirow{2}{*}{$\begin{array}{l}\text { Total } \\
\text { concurrent } \\
\text { time } \\
\text { min. }\end{array}$} & \multirow{2}{*}{$\begin{array}{c}\text { Urine } \\
\text { flow } \\
m l_{.} / \min .\end{array}$} & \multirow[b]{2}{*}{$\underset{m l . / m i n}{C_{I_{n}}}$} & \multirow[b]{2}{*}{$\underset{m l . / m i n}{C_{P A B}}$} & \multirow[b]{2}{*}{$\begin{array}{c}\text { Plasma } \\
\stackrel{P}{\mu} \\
\mu M / m l .\end{array}$} & \multirow[b]{2}{*}{$\begin{array}{c}\text { Urine } \\
\mathbf{P} \\
\boldsymbol{M} / \mathbf{m l} .\end{array}$} & \multicolumn{3}{|c|}{ Phosphate } & \multirow[b]{2}{*}{$\frac{P \text { reab. }}{P_{\text {filt. }}}$} \\
\hline & & & & & & $\begin{array}{l}\text { Filtered } \\
\boldsymbol{\mu} \boldsymbol{M} / \min \text {. }\end{array}$ & $\begin{array}{l}\text { Excreted } \\
\mu M / \min .\end{array}$ & $\begin{array}{l}\text { Reabsorbed } \\
\mu M / \min \text {. }\end{array}$ & \\
\hline $35-39$ & \multicolumn{9}{|c|}{ Prime containing inulin and PAH given } \\
\hline 39 & \multicolumn{9}{|c|}{ Infusion I containing inulin and PAH begun at $3.2 \mathrm{ml}$. per min. } \\
\hline $\begin{array}{r}90-101 \\
101-116\end{array}$ & $\begin{array}{l}11.2 \\
11.3\end{array}$ & $\begin{array}{l}127 \\
130\end{array}$ & $\begin{array}{l}525 \\
541\end{array}$ & $\begin{array}{l}0.91 \\
0.93\end{array}$ & $\begin{array}{l}0.02 \\
0.02\end{array}$ & $\begin{array}{l}116 \\
121\end{array}$ & $\begin{array}{l}0.2 \\
0.2\end{array}$ & $\begin{array}{l}116 \\
121\end{array}$ & $\begin{array}{l}1.00 \\
1.00\end{array}$ \\
\hline 118 & \multicolumn{9}{|c|}{ Infusion II begun; sodium phosphate at $0.55 \mathrm{mM}$ per min. plus inulin and $\mathrm{PAH}$} \\
\hline $\begin{array}{l}148-180 \\
180-214 \\
214-241 \\
241-267\end{array}$ & $\begin{array}{l}4.28 \\
2.92 \\
7.39 \\
5.70\end{array}$ & $\begin{array}{l}133 \\
134 \\
142 \\
138\end{array}$ & $\begin{array}{l}\mathbf{5 2 6} \\
\mathbf{5 0 4} \\
\mathbf{5 6 0} \\
\mathbf{5 0 9}\end{array}$ & $\begin{array}{l}1.95 \\
2.82 \\
3.25 \\
3.49\end{array}$ & $\begin{array}{l}17.5 \\
48.0 \\
29.2 \\
44.5\end{array}$ & $\begin{array}{l}260 \\
378 \\
461 \\
481\end{array}$ & $\begin{array}{r}75 \\
135 \\
216 \\
254\end{array}$ & $\begin{array}{l}185 \\
243 \\
245 \\
227\end{array}$ & $\begin{array}{l}0.71 \\
0.64 \\
0.53 \\
0.47\end{array}$ \\
\hline
\end{tabular}

* Patient C. H., normal male subject, age 17.

ter every 20 to 30 minutes to maintain a water diuresis. Female subjects were catheterized with a six-hole rubber catheter which remained in place throughout the experiment. In the early studies the male subjects were also catheterized. However, it was found that these individuals were able to void on command; hence, catheterization was not performed in later experiments. After a sample of venous blood and one of urine were obtained for determination of inulinoid blank, a priming dose of inulin and PAH calculated to provide plasma levels of 20 and 2 mg. per cent, respectively, was given over a period of 3 to 5 minutes. Constant infusion of these substances dissolved in physiological saline solution was maintained by a pump. Thirty to sixty minutes after the sustaining infusion was begun, timed urine collection periods were started. The period varied in duration from 20 to 40 minutes, and at the midpoint of each, blood was drawn from an antecubital vein into a heparinized syringe, immediately centrifuged, and the plasma separated. To close each period urine was collected by spontaneous voiding or through the catheter followed by irrigation with 20 to $60 \mathrm{ml}$. of distilled water and about $30 \mathrm{ml}$. of air.

After two to four periods the infusion was changed to

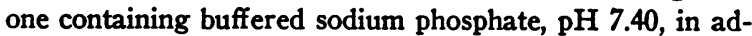
dition to inulin and PAH. A sufficient volume of a $0.5 \mathrm{M}$ phosphate solution was incorporated in the infusion to provide for the delivery of 0.4 to $0.8 \mathrm{mM} \mathrm{P}$ per minute. Such an infusion was continued for sixty minutes before urine collections were again begun. This period was sufficient to allow elevation of the plasma $P$ to the desired levels and to assure a relatively slowly increasing plasma $\mathbf{P}$ concentration during the collection periods. Studies were carried out for two to four periods at the elevated plasma $P$ levels. In some experiments there followed a third infusion designed to elevate further the plasma $P$.

Dietary intake. The low, intermediate and high calcium diets contained 130,800 , and $1500 \mathrm{mg}$., respectively, daily. A low $\mathbf{P}$ intake was achieved by the administration of a diet containing $600 \mathrm{mg}$. of $\mathrm{P}$ daily, and, in sev- eral studies by administering, in addition, $35 \mathrm{ml}$. of aluminum carbonate gel, one hour after each meal and at bedtime. The intermediate $\mathrm{P}$ diet contained $1,200 \mathrm{mg}$., and the high $P$ diets 1800 to $3,000 \mathrm{mg}$. P. In several experiments variations in $\mathrm{Ca}$ or $\mathrm{P}$ intake without changes in other dietary constituents were studied by the administration of a constant low $\mathrm{Ca}$-low $\mathbf{P}$ diet supplemented at meal time with calcium lactate or 10 per cent phosphoric acid. The patient was placed on a given dietary regimen at least three days, and often more than a week prior to the renal function studies.

Chemical methods. Inulin was determined in plasma and urine by the method of Schreiner (10), PAH by the method of Smith, Finkelstein, Aliminosa, Crawford, and Graber (11), inorganic $P$ by the method of Fiske and Subbarow (12). Plasma Ca was determined by the method of Clark and Collip (13), and urine Ca by the method of Shohl and Pedley (14). Plasma $\mathrm{K}$ was determined on a flame photometer utilizing an internal standard.

Calculations. The clearances of inulin and PAH were taken as measures of GFR and RPF, respectively. Filtered $\mathbf{P}$ was calculated as the product of the inulin clearance and the plasma P. Excreted phosphate was calculated as the product of urine $P$ concentration and urine flow. The difference between filtered and excreted $\mathbf{P}$ was considered to be the reabsorbed $P$.

\section{RESULTS}

In thirteen studies on four normal and one hypoparathyroid subjects $P$ reabsorption was determined at endogenous plasma $P$ levels and following stepwise elevations of the plasma P. In all instances a maximal rate of phosphate reabsorption was reached, and further elevation of plasma $P$ resulted in no further increase in the rate of reabsorption. This result is shown for one normal subject in Table I. Following two 
TABLE II

Variation of TmP in nine normals and three hypoparathyroid subjects

\begin{tabular}{|c|c|c|c|c|c|c|c|c|}
\hline \multirow[b]{2}{*}{ Subject } & \multirow[b]{2}{*}{ Date } & \multicolumn{2}{|c|}{ Diet } & \multirow[b]{2}{*}{$\underset{m b . / m i n .}{\text { GFR }}$} & \multirow[b]{2}{*}{$\underset{\mu M / \min }{\operatorname{Tm}}$} & \multirow[b]{2}{*}{$\underset{\mu M / m l .}{\operatorname{TmP}}$} & \multirow{2}{*}{$\begin{array}{c}\text { Standard } \\
\text { deviation } \\
\text { of } \operatorname{TmP} \\
\mu M / \text { min. }\end{array}$} & \multirow{2}{*}{$\begin{array}{c}\text { Coefficien } \\
\text { of } \\
\text { variation } \\
\%\end{array}$} \\
\hline & & $\underset{m g . / d a y}{\mathrm{Ca}}$ & $\underset{m g . / d a y}{P}$ & & & & & \\
\hline \multicolumn{9}{|l|}{$\begin{array}{c}\text { Normal } \\
\text { males } \\
\text { C. H. }\end{array}$} \\
\hline $2.00 \mathrm{M}^{2 *}$ & $\begin{array}{r}3-25-54 \\
4-6-54 \\
11-4-54 \\
11-10-54 \\
12-22-54 \\
3-14-54 \\
\text { Mean }\end{array}$ & $\begin{array}{r}1,500 \\
130 \\
130 \\
1,570 \\
130 \\
1,500\end{array}$ & $\begin{array}{l}1,800 \\
600(\mathrm{~B}) \dagger \\
3,000 \\
600(\mathrm{~B}) \\
600 \\
600\end{array}$ & $\begin{array}{l}147 \\
142 \\
148 \\
138 \\
146 \\
149 \\
145\end{array}$ & $\begin{array}{l}199 \\
222 \\
186 \\
238 \\
219 \\
256 \\
220\end{array}$ & $\begin{array}{l}1.35 \\
1.56 \\
1.26 \\
1.72 \\
1.50 \\
1.72 \\
1.52\end{array}$ & \multirow[t]{2}{*}{25.4} & 11.5 \\
\hline $\begin{array}{l}\text { W. R. } \\
1.76 \mathrm{M}^{2}\end{array}$ & $\begin{array}{r}8-12-54 \\
3-24-55 \\
4-4-55 \\
\text { Mean }\end{array}$ & $\begin{array}{r}2,000 \\
800 \\
130\end{array}$ & $\begin{array}{l}2,800 \\
1,200 \\
600 \text { (B) }\end{array}$ & $\begin{array}{l}114 \\
112 \\
103 \\
110\end{array}$ & $\begin{array}{r}122 \\
75 \\
81 \\
93\end{array}$ & $\begin{array}{l}1.07 \\
0.67 \\
0.79 \\
0.84\end{array}$ & & 27.6 \\
\hline $\begin{array}{l}\text { D. F. } \\
1.94 \mathrm{M}^{2}\end{array}$ & $\begin{array}{c}1-3-55 \\
2-7-55 \\
\text { Mean }\end{array}$ & $\begin{array}{l}610 \\
610\end{array}$ & $\begin{array}{l}1,015 \\
1,015\end{array}$ & $\begin{array}{r}115 \\
99 \\
107\end{array}$ & $\begin{array}{r}102 \\
73 \\
88\end{array}$ & $\begin{array}{l}0.89 \\
0.74 \\
0.81\end{array}$ & 11.3 & 12.9 \\
\hline $1.91 \mathrm{M}^{2}$ & $\begin{array}{r}6-10-54 \\
6-22-54 \\
\text { Mean }\end{array}$ & High & $\begin{array}{l}900(\mathrm{~B}) \\
\text { High }\end{array}$ & $\begin{array}{l}109 \\
121 \\
115\end{array}$ & $\begin{array}{l}179 \\
175 \\
177\end{array}$ & $\begin{array}{l}1.64 \\
1.45 \\
1.54\end{array}$ & \multirow[t]{3}{*}{2.7} & \multirow[t]{3}{*}{1.5} \\
\hline $\begin{array}{c}\text { M. L. } \\
2.10 \mathrm{M}^{2} \\
\text { L. B. }\end{array}$ & $12-14-54$ & High & High & 151 & 159 & 1.05 & & \\
\hline $1.91 \mathrm{M}^{2}$ & $11-17-54$ & High & High & 138 & 125 & 0.90 & & \\
\hline \multicolumn{9}{|l|}{$\begin{array}{l}\text { Normal } \\
\text { females }\end{array}$} \\
\hline$\underset{1.78 \mathrm{M}^{2}}{\text { R. }}$ & $\begin{array}{r}1-17-55 \\
2-3-55 \\
3-3-55 \\
3-28-55 \\
4-14-55 \\
\text { Mean }\end{array}$ & $\begin{array}{r}130 \\
1,500 \\
130 \\
130 \\
2,200\end{array}$ & $\begin{array}{r}600 \\
600 \\
1,600 \\
3,000 \\
3,000\end{array}$ & $\begin{array}{l}115 \\
112 \\
118 \\
145 \\
138 \\
126\end{array}$ & $\begin{array}{l}137 \\
105 \\
120 \\
101 \\
111 \\
115\end{array}$ & $\begin{array}{l}1.19 \\
0.94 \\
1.02 \\
0.70 \\
1.24 \\
0.91\end{array}$ & 14.3 & 12.4 \\
\hline $1.82 \mathrm{M}^{2}$ & $\begin{array}{r}5-25-55 \\
6-15-55 \\
\text { Mean }\end{array}$ & $\begin{array}{r}130 \\
1,500\end{array}$ & $\begin{array}{l}600(\mathrm{~B}) \\
1,800\end{array}$ & $\begin{array}{l}142 \\
131 \\
136\end{array}$ & $\begin{array}{l}185 \\
198 \\
191\end{array}$ & $\begin{array}{l}1.30 \\
1.51 \\
1.40\end{array}$ & \multirow[t]{2}{*}{9.2} & \multirow[t]{2}{*}{4.8} \\
\hline$\underset{1.77}{\text { E. }} \mathrm{M}^{2}$ & $3-21-55$ & Medium & Medium & 96 & 108 & 1.15 & & \\
\hline \multicolumn{9}{|l|}{$\begin{array}{c}\text { Hypo- } \\
\text { parathyroid }\end{array}$} \\
\hline $\begin{array}{l}\text { A. W. } \\
65 \text { kg. }\end{array}$ & $\begin{array}{r}8-25-54 \\
9-14-54 \\
10-20-54 \\
1-10-55 \\
2-21-55 \\
\text { Mean } \\
3-9-55 \\
2-9-55\end{array}$ & $\begin{array}{r}4,400 \\
2,200 \\
3,300 \\
130 \\
2,200 \\
\quad \text { Incor } \\
2,000\end{array}$ & $\begin{array}{l}1,200 \\
600(\mathrm{~B}) \\
600 \\
600 \\
700\end{array}$ & $\begin{array}{r}96 \\
88 \\
84 \\
95 \\
110 \\
95 \\
76 \\
73\end{array}$ & $\begin{array}{r}158 \\
163 \\
172 \\
179 \\
149 \\
164 \\
102 \\
98\end{array}$ & $\begin{array}{l}1.65 \\
1.85 \\
2.04 \\
1.88 \\
1.35 \\
1.75 \\
1.34 \\
1.34\end{array}$ & 11.7 & 7.1 \\
\hline
\end{tabular}

* Surface area.

$t(B)=$ Basaljel.

periods at endogenous plasma $P$ levels, buffered sodium phosphate was administered, and the plasma $\mathrm{P}$ and, hence, the filtered $\mathrm{P}$ rose. The initial increase in filtered $P$ noted in periods three and four (148 to 180 minutes, and 180 to $214 \mathrm{~min}$ utes) resulted in a rise in both reabsorbed and 
excreted P. However, with the further elevation of plasma and filtered $\mathrm{P}$, noted in periods five and six, no increase in reabsorbed $P$ resulted, indicating that a maximal rate of reabsorption had been reached. This relationship between filtered and reabsorbed $\mathrm{P}$ is shown in Figure 1, which presents a similar study in a hypoparathyroid subject (A. W.). The constancy of $\mathrm{P}$ reabsorption at elevated plasma $\mathrm{P}$ levels resulted in a reduction in the ratio of filtered $\mathrm{P} /$ reabsorbed $\mathrm{P}$ with further increases in the filtered load. This was a consistent finding and is shown for one experiment in the last column of Table I. In both of these studies endogenous urinary $\mathrm{P}$ excretion was reduced by the prior administration of a low $\mathrm{P}$ diet and aluminum carbonate gel. The Tm phenomenon was also noted in patients not given aluminum carbonate gel.

Repeated determinations of $\mathrm{TmP}$ in the same individual over a period of weeks or months indicated considerable variability in most subjects. The mean values of $\mathrm{TmP}$ on different days for five normal subjects (C. H., W. R., D. F., J. N., R. H.) and one hypoparathyroid individual (A. W.) are shown in Table II. The standard deviation of the mean and the coefficient of variation are included as indices of the variability. The TmP values listed in Table II were obtained at different dietary levels of $\mathrm{Ca}$ and $\mathrm{P}$. The relationship of dietary $\mathrm{Ca}$ and $\mathrm{P}$ to $\mathrm{TmP}$ was investigated. In two normal individuals, C. H. and R. H., intensive studies of the effect of changes in dietary $\mathrm{Ca}$ and $\mathrm{P}$ on $\mathrm{TmP}$ were made, and less complete studies were carried out on four other normal and one hypoparathyroid (A.W.) subjects. Analysis of the results indicated that variations of $\mathrm{TmP}$ from one period to another on a given day were about as great as the variations on different dietary regimens in all but two subjects (C. H. and E. P.). Since C. $\mathrm{H}$. was one of the two subjects in whom an extensive study of the effects of changes in dietary $\mathrm{Ca}$ and $\mathrm{P}$ was made, these results are considered worthy of mention. The highest TmP values were obtained when the patient was on a high Ca-low $\mathrm{P}$ intake, (11-10-54, 3-14-55) and the next highest when on a low Ca-low $\mathrm{P}$ diet (4-6-54). These results are shown in Table II.

It is of interest that the individuals who showed the greatest variation in $\mathrm{TmP}$ between experiments also showed the largest fluctuations within
TABLE III

Variations of $T m P$ with relative constancy of $C_{I_{n}}$ and $C_{P A H}$ in two experiments on a normal subject *

\begin{tabular}{lcccc}
\hline \hline Date & $\begin{array}{c}\text { Total } \\
\text { concurrent } \\
\text { time } \\
\text { min. }\end{array}$ & $\begin{array}{c}\text { Cin } \\
\text { ml./min. }\end{array}$ & $\begin{array}{c}\text { Cpar } \\
\text { ml./min. }\end{array}$ & $\begin{array}{c}\text { TmP } \\
\mu M / m i n\end{array}$ \\
\hline $3-24-55$ & $105-141$ & 110 & 670 & 61 \\
& $141-171$ & 111 & 652 & 74 \\
& $171-188$ & 114 & 636 & 89 \\
$4-4-55$ & $128-158$ & 102 & 522 & 104 \\
& $158-182$ & 101 & 566 & 95 \\
& $182-214$ & 104 & 556 & 44 \\
\hline
\end{tabular}

*W. R., 22-year-old normal male.

a given experiment. That this does not appear to be due to technically poorer experiments or to overall fluctuations in renal function in these individuals is suggested by the fact that the inulin and $\mathrm{PAH}$ clearances did not reveal large changes from period to period. This is illustrated in two experiments on W. R., a normal subject (Table III). It can be seen that although the clearances of inulin and $\mathrm{PAH}$ were fairly constant, there is considerable fluctuation in TmP. These results are in contrast to the small variations in $\mathrm{TmP}$ in a given experiment noted in some of the other normal subjects. The data suggest that physiological variations in $\mathrm{TmP}$ of considerable magnitude may occur over short time intervals.

No consistent change in TmP was noted to occur in the course of an experiment. Although most of the experiments lasted from two to five hours, in two experiments on two normal subjects phosphate was infused for fourteen and eighteen hours. No appreciable change in $\mathrm{TmP}$ was noted during, or at the end of this period of time.

Plasma calcium was usually reduced when phosphate was infused, and the degree of reduction appeared to be correlated with the magnitude of the increase in plasma $P$. In the normal individuals the plasma $\mathrm{Ca}$ never fell below $8 \mathrm{mg}$. per cent, and at no time was tetany produced. In two of the hypoparathyroid individuals mild tetany did result during $\mathrm{P}$ infusions.

Although the plasma $\mathrm{K}$ was often lowered immediately after a $\mathrm{P}$ infusion was begun, there was little change thereafter, and no correlation could be made between changes in plasma $K$ and variations of $\mathrm{TmP}$.

The variability of $\mathrm{TmP}$ among the normal indi- 
viduals cannot be accounted for by differences in body size (Table II). Calculations of TmP per unit of surface area did not appreciably alter the wide range of values for $\mathrm{TmP}$. The average $\mathrm{TmP}$ for the three hypoparathyroid subjects falls within the broad range of values found for the normals (Table II). Insufficient data were obtained to determine whether the variability of $\mathrm{TmP}$ on repeated determinations was significantly different than in normal individuals. A single study on one hyperparathyroid subject revealed a mean TmP of $26 \mu \mathrm{M}$ per min., a figure distinctly lower than that seen in the normal subjects.

No consistent relationship between GFR and TmP was noted (Table II). The variability of the ratio $\mathrm{TmP} / \mathrm{GFR}$ is greater than that found for glucose (TmG/GFR) by Smith and his co-workers (15). They found that in normal individuals the coefficient of variation for TmG/GFR was 15 per cent. The coefficient of variation for $\mathrm{TmP} /$ GFR in the normal subjects included in Table II is 30 per cent.

\section{DISCUSSION}

Our data are in accord with the observations in the dog (1-5) and in man (6) which indicate that there is a maximal rate of phosphate reabsorption by the renal tubules. These results are in contrast to those obtained by Smith, Ollayos, and Winkler (7), Eggleton and Shuster (8), and Crawford, Gribetz, and Talbot (9), who found increased $P$ reabsorption with increased filtered $P$ without any apparent Tm. Furthermore, our results do not indicate that $\mathrm{P}$ reabsorption is conditioned by GFR at elevated plasma $P$ levels such that a constant fraction of filtered $P$ is reabsorbed. Were this conditioning to exist, the ratio, $P$ reabsorbed/ GFR, would remain constant. The data in Table II indicate that this ratio is quite variable.

It is apparent that there is a considerable variability in $\mathrm{TmP}$ in a given individual and between individuals. For the most part this variability remains unexplained. The attempt to correlate $\mathrm{TmP}$ with the dietary level of $\mathrm{Ca}$ and $\mathrm{P}$ in our studies has been inconclusive. A correlation between the level of phosphate in the diet and phosphate reabsorption has been demonstrated in rats (16), dogs (17) and newborn infants (18). A high level of $P$ intake was associated with a reduction in $\mathrm{P}$ reabsorption. Our failure to demonstrate a clear-cut effect on $\operatorname{TmP}$ with an elevated $P$ intake may be related to the fact that the amount of dietary $P$ per $\mathrm{kg}$. of body weight was lower than that achieved in rats (16) and in infants (18). That factors other than diet influence phosphate reabsorption is known. Roberts and Pitts showed that the administration of cortisone to dogs consistently reduced $\operatorname{TmP}$ (19). A reduction in $\operatorname{TmP}$ with prolonged $P$ infusions has been shown by Michie (20) and by Hogben and Bollman (2). The latter workers showed in studies on dogs that this reduction was usually accompanied by a decrease in plasma $\mathrm{K}$, and that addition of $\mathrm{K}$ to the infusion reversed the drop in $\mathrm{Tm}$. In the occasional instance in our studies where TmP fell during an experiment there was no associated decrease in plasma K. Our experiments were usually short in comparison with those of Hogben and Bollman, and it is possible that we might have seen reductions in $\mathrm{TmP}$ and plasma $\mathrm{K}$ if the experiments had been prolonged. However, in two experiments on two normal subjects in which prolonged $P$ infusions were given no decrease in TmP was noted. Clearly, our data do not reveal the cause of fluctuations in TmP. Elucidation of these factors will require further experimentation.

The range of values for $\mathrm{TmP}$ in this group of normal subjects makes the use of any average figure of little value and indicates the necessity of using the subject as his own control in any study designed to evaluate factors influencing TmP. Furthermore, the uncontrolled and unexplained "spontaneous fluctuations" in TmP make it apparent that small changes in TmP cannot be accepted as significant without critical analysis of control studies.

Certain considerations of the mechanism of phosphate reabsorption are pertinent to an evaluation of our data. The reabsorption of phosphate, like that of glucose, shows a limited maximal transfer rate. However, differences exist in the transfer characteristics of these two substances. Whereas the maximal rate of glucose transport is quite constant in any one individual and between individuals (when differences in body surface area are taken into consideration), the maximal rate of phosphate reabsorption is more variable. What is the significance of this fact? The maximal rate of glucose reabsorption is considerably 
greater than is required for total reabsorption even with physiological variations in load. Thus, the kidney serves to conserve the body stores of glucose and is not normally an important regulator of plasma concentration. On the other hand, the Tm for phosphate is only slightly greater, and in some instances no greater, than reabsorption at endogenous plasma levels. Hence, relatively small changes in $\mathrm{Tm}$ would be expected to affect the plasma concentration of phosphate, whereas this would not be true for glucose. It may be postulated that the considerable variability of TmP is due to factors which act upon the phosphate transport mechanism to alter reabsorption of phosphate, thus providing an important mechanism for the regulation of plasma phosphate concentration. Our studies and those of others have indicated that a parathyroid hormone is one factor of importance in the regulation of phosphate transport in the renal tubule $(4,21-23)$.

A consideration of maximal reabsorptive and secretory rates in the renal tubules led Shannon to a general kinetic analysis for Tm substances (24). Similar kinetic considerations apply to any enzyme-catalyzed reaction where the reaction rate reaches a maximum value with increasing substrate concentration (plasma concentration) because of enzyme saturation. The maximal rate of renal tubular transport of any substance $(\mathrm{Tm})$ may be visualized as that rate which is observed when the enzyme system(s) involved is saturated with regard to substrate. Since factors (e.g., parathyroid hormone) other than substrate concentration may influence the activity of the enzyme system it is not surprising to find that variations in $\mathrm{Tm}$ values occur. It seems likely that an explanation of the variability of $\mathrm{TmP}$ will require an understanding of the mechanisms by which substances exert their effects on the enzymes involved in phosphate transport.

\section{SUMMARY AND CONCLUSIONS}

1. A maximal renal tubular rate of reabsorption of phosphate $(\mathrm{TmP})$ has been demonstrated in normal and hypoparathyroid subjects.

2. In man considerable variability in $\mathrm{TmP}$ often occurs within a given experiment and also between experiments. This variability remains unexplained.

3. Dietary variations in calcium and phosphorus produced no consistent changes in TmP. Data in one subject suggested that $\mathrm{TmP}$ is greatest when the dietary level of $P$ is low, and least when dietary $\mathrm{P}$ is high.

4. Comparison of $\mathrm{TmP}$ between normal individuals indicated a wide range of values.

5. The values for TmP in hypoparathyroid subjects fell within the broad range of normal. The $\mathrm{TmP}$ in one hyperparathyroid subject fell below the normal range.

6. Because of the variability of $\mathrm{TmP}$ in a given individual and between individuals each subject must serve as his own control in any study designed to determine the influence of an experimental regimen on phosphate reabsorption.

7. The possible significance of the variability of $\mathrm{TmP}$ is discussed in relation to current concepts of transport mechanisms.

\section{ACKNOWLEDGMENTS}

We wish to express our gratitude to Misses Mary Margaret Brown and Doris Graves for their technical assistance.

\section{REFERENCES}

1. Pitts, R. F., and Alexander, R. S., The renal reabsorptive mechanism for inorganic phosphate in normal and acidotic dogs. Am. J. Physiol., 1944, 142, 648.

2. Hogben, C. A. M., and Bollman, J. L., Renal reabsorption of phosphate; normal and thyroparathyroidectomized dog. Am. J. Physiol., 1951, 164, 670.

3. Jahan, I., and Pitts, R. F., Effect of parathyroid on renal tubular reabsorption of phosphate and calcium. Am. J. Physiol., 1948, 155, 42.

4. Harrison, H. E., and Harrison, H. C., The renal excretion of inorganic phosphate in relation to the action of vitamin $\mathrm{D}$ and parathyroid hormone. J. Clin. Invest., 1941, 20, 47.

5. Ayer, J. L., Schiess, W. A., and Pitts, R. F., Independence of phosphate reabsorption and glomerular filtration in the dog. Am. J. Physiol., 1947, 151, 168.

6. Schiess, W. A., Ayer, J. L., Lotspeich, W. D., and Pitts, R. F., The renal regulation of acid-base balance in man. II. Factors affecting the excretion of titratable acid by the normal human subject. J. Clin. Invest., 1948, 27, 57.

7. Smith, P. K., Ollayos, R. W., and Winkler, A. W., Tubular reabsorption of phosphate in the dog. J. Clin. Invest., 1943, 22, 143.

8. Eggleton, M. G., and Shuster, S., Glucose and phosphate excretion in the cat. J. Physiol., 1954, 124, 613. 
9. Crawford, J. D., Gribetz, D., and Talbot, N. B., Mechanism of renal tubular phosphate reabsorption and the influence thereon of vitamin $D$ in completely parathyroidectomized rats. Am. J. Physiol., 1955, 180, 156.

10. Schreiner, G. E., Determination of inulin by means of resorcinol. Proc. Soc. Exper. Biol. \& Med., 1950, 74, 117.

11. Smith, H. W., Finkelstein, N., Aliminosa, L., Crawford, B., and Graber, M., The renal clearances of substituted hippuric acid derivatives and other aromatic acids in dog and man. J. Clin. Invest., $1945,24,388$.

12. Fiske, C. H., and Subbarow, Y., The colorimetric determination of phosphorus. J. Biol. Chem., 1925, $66,375$.

13. Clark, E. P., and Collip, J. B., A study of the Tisdall method for the determination of blood serum calcium with a suggested modification. J. Biol. Chem., 1925, 63, 461.

14. Shohl, A. T., and Pedley, F. G., A rapid and accurate method for calcium in urine. J. Biol. Chem., 1922, 50, 537.

15. Smith, H. W., The Kidney: Structure and Function in Health and Disease. New York, Oxford University Press, 1951, p. 94.

16. Crawford, J. D., Osborne, M. M., Jr., Talbot, N. B., Terry, M. L., and Morrill, M. F., The parathyroid glands and phosphorus homeostasis. J. Clin. Invest., 1950, 29, 1448.

17. Foulks, J. G., Homeostatic adjustment in the renal tubular transport of inorganic phosphate in the dog. Canad. J. Biochem. \& Physiol., 1955, 33, 638.

18. McCrory, W. W., Forman, C. W., McNamara, H., and Barnett, H. L., Renal excretion of inorganic phosphate in newborn infants. J. Clin. Invest., 1952, 31, 357.

19. Roberts, K. E., and Pitts, R. F., The effects of cortisone and desoxycorticosterone on the renal tubular reabsorption of phosphate and the excretion of titratable acid and potassium in dogs. Endocrinology, 1953, 52, 324.

20. Michie, A. J., Effect of parathyroid hormone on renal excretion of phosphate. Report of 4th $M \& R$ Pediatric Research Conference, 1952, p. 46.

21. Albright, F., Bauer, W., Ropes, M., and Aub, J. C., Studies of calcium and phosphorus metabolism. IV. The effect of parathyroid hormone. J. Clin. Invest., 1929, 7, 139.

22. Handler, P., and Cohn, D. V., Effect of parathyroid extract on renal function. Am. J. Physiol., 1952, $169,188$.

23. Hiatt, H. H., and Thompson, D. D., The effects of parathyroid extract on renal function in man. J. Clin. Invest., 1957, 36, 557.

24. Shannon, J. A., Renal tubular excretion. Physiol. Rev., 1939, 19, 63.

\section{ANNOUNCEMENT OF MEETING}

The 49th Annual Meeting of the American Society for Clinical Investigation will be held in Atlantic City, New Jersey, on Monday, May 6, 1957, with headquarters at the Chalfonte-Haddon Hall. The scientific session will begin at 9 A.M. at the Steel Pier Theater. 